(Previously Prace Naukowe Instytutu Gornictwa Politechniki Wroclawskiej, ISSN 0370-0798)

ISSN 2300-9586 (print)

ISSN 2353-5423 (online)

Received September 27, 2019; reviewed; accepted April 15, 2020

\title{
STUDY OF THE MECHANICAL BEHAVIOR AND DURABILITY OF MORTARS BASED ON PREPARED SAND
}

Ammar NOUI ${ }^{1 *}$, Mohammed Sallah BOUGLADA ${ }^{1}$, Larbi BELAGRAA ${ }^{2}$, Yacine ACHOUR ${ }^{1}$, Bouzid ABDERAZAK ${ }^{3}$

${ }^{1}$ Department of Civil Engineering, Faculty of Science and Technology, Elbachir El Ibrahimi University, Bordj Bou Arréridj University, 34030, Algeria

${ }^{2}$ Department of Civil Engineering Faculty of Technology, University Med Boudiaf of M'sila, Algeria (28.000)

${ }^{3}$ Department of Material Science, Faculty of Science and Technology, Elbachir El Ibrahimi University, Bordj Bou Arréridj University, 34 030, Algeria

\begin{abstract}
Sand occupies a great proportion of the cementitious matrix product and in particular mortars. Hence, the study of fine aggregates used for concrete and mortar in general, deserves to be objects of research including sand which has always been considered as inert material, whose role is exclusively physical. The study of mortars performances based on prepared sand to assess the effect of the type and rate of substitution of mineral additions pozzolana and blast furnace slag of a natural sand fine fraction (sieve diameter less than $0.16 \mathrm{~mm}$ ) is seen as the main objective of the present experimental research work. The natural sand replaced size is less than $160 \mu \mathrm{m}$ and for rheological reasons the maximum replacement rate of natural sand is limited to $10 \%$. The results obtained show a significant improvement of the mechanical properties for the mortars based on the new activated sand. With regard to durability tests of $\mathrm{HCl}$ and $\mathrm{H}_{2} \mathrm{SO}_{4}$ acids chemical attacks, the substitution of the quartz by active mineral additions in the sand-size skeleton allows an advantageous reduction in loss of resistance up to $50 \%$ and a mass gain around $75 \%$.
\end{abstract}

Keywords: mineral additions substitution, natural sand, activated sand, mechanical characteristics, durability

* Corresponding author: ammananova@gmail.com (N. Ammar)

doi: $10.37190 / \mathrm{msc} 202704$ 


\section{INTRODUCTION}

Sand is the constituent of the granular skeleton that has a physico-mechanical impact on the quality of mortars and concrete, this material is widely available at reduced cost. It must be clean and contain no harmful elements to reduce the volume variations of cementitious materials. On the other hand, considering their cost and their availability, using active additives in sand composition could contribute positively in the process of hydration and improvement of some characteristics for the cementitious materials (Standard CEN196-1-ISO669b; Dreux, Fiesta 1986).

Due to its economic and safety performance, which is ensured by its intrinsic properties, which are closely linked to the quality of its components, concrete occupies an immense space in the world of construction use (Pouguininseli, 2017). However, there is a growing demand to replace PC concrete by alkali-activated concrete. These innovative construction materials under certain conditions have lower greenhouse gas and $\mathrm{CO}_{2}$ emissions environmental impacts that is associated with their manufacturing production process (Sedira et al. 2017; Provis, Van Deventer 2009). In the literature, most of the studies of alkali activated materials (AAMs) are bound to the use of only a few precursor materials such as blast furnace slag (Burciaga-Díaz et al. 2013; Fernández-Jiménez et al. 1999; Türker et al. 2016), metakaolin (Alonso, Palomo 2001; Lizcano et al. 2011), and fly ash (Chen et al. 2010; Criado et al. 2010).

The improvement of the qualities of cementitious materials remains of a great concern as the subject of several scientific researches, by studying the various parameters that can influence the performances of concrete and mortars. Especially, those carried out on the cement matrix which was considered of major importance in the determination of the performance of the cementitious materials. This could explain the major interest of the activation of the binder itself.

Nevertheless, the study of the other components of concrete and mortar deserves to be subject of research in particular the sand that is considered as inert material, whose concrete properties are influenced only to these physical properties.

On the other hand, the use of active additives in the granulometric composition of natural sand can transform it to an active material that participate positively in the hydration process (Kerbouche 2009; Noui et al. 2017). It could be noted that a lack of bibliographical matter presented a real handicap in dressing a deep literature review on the actualized subject dealing with activated sand.

This paper proposed an experimental attempt that can give the sand a secondary role in addition to its physical filling one, the reuse of industrial wastes like slag as a replacement for cementitious materials in the sand composition is most promising by the concrete producers. It presents a very good reactivity deal with the cement. Later, different properties where found after the introduction of those active additives to be improved, without compromising its granular proportioning or its quartz dominant nature. This method aimed at activating the sand by additions such as slag and pozzo- 
lan with limited percentages depending on the fraction to be substituted in the particle size composition. This novel activated sand gives the originality of the present subject of research treated here in. Such activation is to give the sand the power to be an influencing factor in the hydration process by the interaction with the cement through its additions which have shown according to several researches a power of hydraulicity and pozzolanity determinant index (Cassagnabère 2011; Noui 2018).

In order to make a contribution to the valorization of dune sand in the manufacture of cementitious materials, we will carry out a preliminary study aiming on the one hand to highlight the influence of sand nature on the mortar mechanical properties. And on the other hand, determine its sustainability in aggressive mediums. The present study, therefore, comes down to a comparative study carried out on two kinds of activated sand prepared in the presence of control sand as a reference mixture.

\section{EXPERIMENTAL PROGRAM}

\subsection{MATERIALS AND TEST PROCEDURES}

\subsubsection{CEMENT AND ADDITIVES}

The cement used is an ordinary portland cement without additions delivered by a local company, with a specific area of $3500 \mathrm{~cm}^{2} / \mathrm{g}$ and a bulk density of 3.2 . The pozzolan is a local byproduct of iron ore processing obtained from a steel manufacturing plant in the east of Algeria. The pozzolan composition can vary within wide limits, depending on the nature of the ore $\left(\mathrm{SSB}=2300 \mathrm{~cm}^{2} / \mathrm{g}\right)$. The slag used in this study is a waste of the steel local company $\left(\mathrm{SSB}=2400 \mathrm{~cm}^{2} / \mathrm{g}\right)$. The fineness of the additions used must be identical to the fractions intended to be substituted (between 80 and $160 \mu)$. The chemical and mineralogical composition of cement and additions are given in Table 1.

Table. 1. The chemical and mineralogical composition of materials

\begin{tabular}{|l|c|c|c|c|c|c|c|c|c|c|c|}
\hline & $\mathrm{SiO}_{2}$ & $\mathrm{Al}_{2} \mathrm{O}_{3}$ & $\mathrm{Fe}_{2} \mathrm{O}_{3}$ & $\mathrm{CaO}$ & $\mathrm{MgO}$ & $\mathrm{SO}_{3}$ & $\mathrm{Na}_{2} \mathrm{O}$ & $\mathrm{K}_{2} \mathrm{O}$ & $\mathrm{Cl}^{-}$ & L.O.I & $\Sigma(\%)$ \\
\hline Cement & 21,57 & 4,37 & 5,27 & 64,31 & 1.43 & 0.72 & - & 0,38 & 0,01 & 0,98 & 99,04 \\
\hline Slag & 29,84 & 5,64 & 4,98 & 28,04 & 1,57 & 1,11 & - & 1,04 & 0,01 & 27,77 & 100.00 \\
\hline Pozzolan & 45.59 & 17.81 & 9.04 & 10.71 & 3.48 & 0.21 & 5.12 & 1.04 & 0,01 & 6.96 & 99.97 \\
\hline
\end{tabular}

2.1.2. SAND

The local desert sand is used from the region of OUED SOUF (South-East of Algeria), which has an equivalent sand modulus before washing equal to 81.80 and a fineness modulus around 2.41 , which shows the good quality of this natural sand that is prepared following the steps. 
Firstly, washing is carried out by the continuous use of hot water two or three times, to avoid the presence of all the harmful elements (presence of some very fine particles of white color).

Then the sample is air dried. After that a sieving operation in a clean and dry sieve column series of $2.0,1.6,1.00,0.5,0.16,0.08 \mathrm{~mm}$ is performed. The fractions of the quartz were mixed as shown in Table 2 and packed in bags of $1350 \pm 5 \mathrm{~g}$ to be used for the preparation of the mortar mixtures later on.

Table 2. Sieve analysis and granular composition of control sand

\begin{tabular}{|c|c|c|c|c|}
\hline Fraction & Percentage & Quartz (Qtz) & Slag (Slg) & Pozzolan (Pz) \\
\hline $0.08-0.16$ & $15 \%$ & $202.5 \mathrm{~g}$ & - & - \\
\hline $0.16-0.5$ & $20 \%$ & $270 \mathrm{~g}$ & - & - \\
\hline $0.5-1$ & $36 \%$ & $486 \mathrm{~g}$ & - & - \\
\hline $1-1.6$ & $19 \%$ & $256.5 \mathrm{~g}$ & - & - \\
\hline $1.6-2,0$ & $10 \%$ & $135 \mathrm{~g}$ & - & - \\
\hline$\Sigma$ & $100 \%$ & $1350 \mathrm{~g}$ & & \\
\hline
\end{tabular}

\subsection{DESIGN}

To identify the benefits and the optimal rate of substitution of a part of the finer fraction of sand, we opted to making four mixtures for each type of addition (slag and pozzolan), the replacement amount rate ranges from 2.5 to $10 \%$ with a step increment of $2.5 \%$.

Table 3. The composition of prepared sand

\begin{tabular}{|c|c|c|c|c|c|c|}
\hline \multirow{2}{*}{$\begin{array}{l}\text { Fraction } \\
(\mathrm{mm})\end{array}$} & \multirow{2}{*}{ Rate } & \multirow{2}{*}{ Control } & \multicolumn{4}{|c|}{ Sand with pozzolana } \\
\hline & & & S.PZ 1 & S.PZ 2 & S.PZ 3 & S.PZ 4 \\
\hline $0,08-0,16$ & $15 \%$ & $15 \%$ Qtz & $\begin{array}{c}2.5 \% \mathrm{Pz} \\
+12,5 \% \mathrm{Qtz}\end{array}$ & $\begin{array}{c}5 \% \mathrm{Pz} \\
+10 \% \mathrm{Qtz}\end{array}$ & $\begin{aligned} & 7.5 \% \mathrm{Pz} \\
+ & 7,5 \% \mathrm{Qtz}\end{aligned}$ & $\begin{array}{c}10 \% \mathrm{Pz} \\
+5 \% \mathrm{Qtz}\end{array}$ \\
\hline \multirow{2}{*}{$\begin{array}{l}\text { Fraction } \\
(\mathrm{mm})\end{array}$} & \multirow{2}{*}{ Rate } & \multirow{2}{*}{ Control } & \multicolumn{4}{|c|}{ Sand with Slag } \\
\hline & & & S.Slg 1 & S.Slg2 & S.Slg3 & S.Slg4 \\
\hline $0,08-0,16$ & $15 \%$ & $15 \%$ Qtz & $\begin{array}{c}2.5 \% \mathrm{Slg} \\
+12,5 \% \text { Qtz }\end{array}$ & $\begin{array}{c}5 \% \mathrm{Slg} \\
+10 \% \mathrm{Qtz}\end{array}$ & $\begin{array}{l}7.5 \% \mathrm{Slg} \\
+7,5 \% \mathrm{Qtz}\end{array}$ & $\begin{array}{r}10 \% \mathrm{Slg} \\
+5 \% \mathrm{Qtz}\end{array}$ \\
\hline
\end{tabular}

S.Pz: Sand with pozzolana; S.Slg: Sand with Slag; Qtz: Quartz Sand.

The following remarks are to be taken into account for the prepared samples:

- For prepared sands, the total replacement rate concerns the fraction from 80 to $160 \mu$;

- Prepared sands are of standardized grain size; 
- For rheological reasons; the optimal rate is estimated at $10 \%$ so as not to exceed the $\mathrm{W} / \mathrm{C}$ ratio of a standardized mortar.

The sets of mortar obtained are related respectively to the proportions of the additions used in each mix. The mortar specimens adopted the following proportions $1 / 4$ cement, $3 / 4$ sand and water cement ratio w/c equals to 0.5 . Prismatic specimens of dimensions $(40 \times 40 \times 60) \mathrm{mm}^{3}$ were used. After twenty four hours, specimens were demolded and cured in the water until the due age of testing for compressive strength and durability. The different proportions for the mortar mixtures series prepared are given in Table 3.

\section{TESTING}

The flexural and compressive strength tests of the behavior of the different mortars mixtures prepared were conducted according to European standards (NA EN 12390-3, 2009; NA EN 12390-6, 2003).

The durability tests (loss of weight and compressive strength loss) were carried out on mortar specimens made from these prepared sand which contain mineral additions at different percentages and an identical fineness. The specimens were kept in chemical aggressive solutions ( $\mathrm{HCl}$ and $\left.\mathrm{H}_{2} \mathrm{SO}_{4}\right)$ after 28 days of water cure till the age of testing at 56 days.

\section{RESULTS AND DISCUSSION}

\subsection{COMPRESSIVE AND FLEXURAL STRENGTHS}

The comparison of the development for the mechanical strengths according to the age of two sets of mortars are shown in Tables 4 and 5, and Figs. 6 and 7.

The results obtained show that at 28 days of age mortars produced strengths exceeding the required known values for conventional mortars. The compressive strengths obtained at 2 and 7 days of hardening are much more acceptable for all the mortars, the flexural strengths values range from 5 to $6 \mathrm{MPa}$ and compressive strengths between 20 and $38 \mathrm{MPa}$. The significant resistances increase of more than $35 \%$ at 28 days is registered. The results presented in Figs. 1 and 2 show that mortars based on the new sands have an increase in the compressive strength reaching $23 \%$ for sands based on slag addition and $28 \%$ for sands based on pozzolana. This holds up to be around $38 \%$ at a 120 days cure period for both types of prepared sand. This is in good agreement with results obtained by other researchers (Noui, Zeghichi 2017; Belagraa, Bouzid 2016; Kerbouche 2009). 
A. NOUI. et al.

Table 4. The Compressive strength results for the different studied mortars

\begin{tabular}{|c|c|c|c|c|c|c|}
\hline \multirow{2}{*}{\multicolumn{2}{|c|}{ Sand type }} & \multirow{2}{*}{$\begin{array}{c}\text { Addition } \\
(\%)\end{array}$} & \multicolumn{4}{|c|}{$\begin{array}{c}\text { Compressive strength in (MPa) } \\
\text { at the age (days) }\end{array}$} \\
\hline & & & 2 & 7 & 28 & 120 \\
\hline \multicolumn{2}{|c|}{ Control sand } & 0 & 21.18 & 31.98 & 43.36 & 51.05 \\
\hline \multirow{4}{*}{$\begin{array}{l}\text { Sand with } \\
\text { pozzolana }\end{array}$} & S.PZ $_{1}$ & 2.5 & 22.28 & 32.11 & 44.38 & 55.54 \\
\hline & S.PZ 2 & 5 & 20.23 & 32.47 & 49.14 & 62.13 \\
\hline & S.PZ 3 & 7.5 & 29.89 & 32.06 & 52.17 & 64.92 \\
\hline & S.PZ 4 & 10 & 29.35 & 36.98 & 53.69 & 69.00 \\
\hline \multirow{4}{*}{$\begin{array}{l}\text { Sand with } \\
\text { Slag }\end{array}$} & S.Slg & 2.5 & 21.90 & 33.34 & 48.43 & 60.34 \\
\hline & S.Slg 2 & 5 & 26.33 & 33.41 & 51.10 & 62.97 \\
\hline & S.Slg & 7.5 & 28.14 & 35.10 & 53.33 & 67.60 \\
\hline & S.Slg 4 & 10 & 24.86 & 38.35 & 55.56 & 70.48 \\
\hline
\end{tabular}

Table 5. The flexural strength results for the different studied mortars

\begin{tabular}{|c|c|c|c|c|c|c|}
\hline \multirow{2}{*}{\multicolumn{2}{|c|}{ Sand type }} & \multirow{2}{*}{$\begin{array}{l}\text { Addition } \\
(\%)\end{array}$} & \multicolumn{4}{|c|}{$\begin{array}{l}\text { Flexural strength }(\mathrm{MPa}) \\
\text { at the age (days) }\end{array}$} \\
\hline & & & 2 & 7 & 28 & 120 \\
\hline \multicolumn{2}{|c|}{ Control Sand } & 0 & 5.16 & 6.29 & 5.94 & 7.31 \\
\hline \multirow{4}{*}{$\begin{array}{l}\text { Sand with } \\
\text { pozzolana }\end{array}$} & S.PZ 1 & 2.5 & 5.71 & 6.00 & 6.18 & 6.98 \\
\hline & S.PZ & 5 & 5.05 & 5.99 & 6.62 & 8.45 \\
\hline & $\mathrm{S}_{\mathrm{SPZ}}$ & 7.5 & 5.56 & 5.81 & 5.60 & 9.71 \\
\hline & $\mathrm{S}_{\mathrm{SPZ}}$ & 10 & 5.47 & 6.25 & 6.21 & 10.80 \\
\hline \multirow{4}{*}{$\begin{array}{l}\text { Sand with } \\
\text { Slag }\end{array}$} & S.Slg & 2.5 & 5.22 & 6.16 & 6.92 & 8.73 \\
\hline & S.Slg 2 & 5 & 5.33 & 6.02 & 6.69 & 8.33 \\
\hline & S.Slg & 7.5 & 5.72 & 6.84 & 6.89 & 10.12 \\
\hline & S.Slg & 10 & 5.59 & 6.32 & 8.25 & 11.64 \\
\hline
\end{tabular}

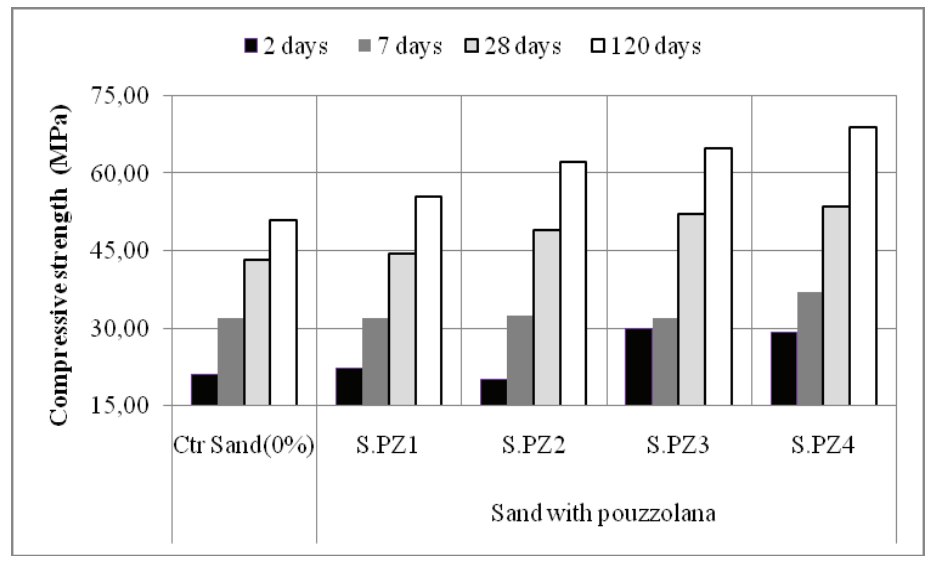

Fig. 1. Compressive strength developments as a function of the age for different mixtures (sand with pozzolan) 


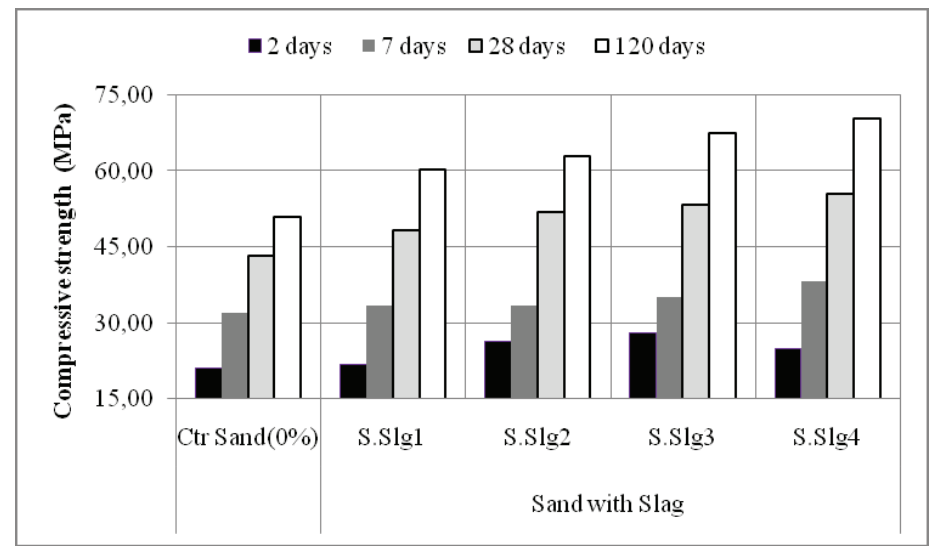

Fig. 2. Compressive strength developments as a function of the age for different mixtures (Sand with Slag)

In this study, we also determined a significant evolution of compressive strength for the different mixtures at 120 days, especially for sand that contains a great amount of slag (10\%), The results presented in Figs. 1 and 2 show that the compressive strength increases from $53,7 \mathrm{MPa}$ at 28 days to $69 \mathrm{MPa}$ at 120 days for mixtures with Pozzolana and from 55.6 MPa at 28 days to $70.5 \mathrm{MPa}$ at 120 days for mixtures with blast furnace slag. The high reactivity of slag in the medium and long term is related to the silicate phases that compose them, as well as to their specific surface area comparable to that of cement. The silicate phases consume Portlandite and produce very high secondary C-S-H and C, A-S-H (Badogiannis 2002; Khatib 2004; Saillio 2012).

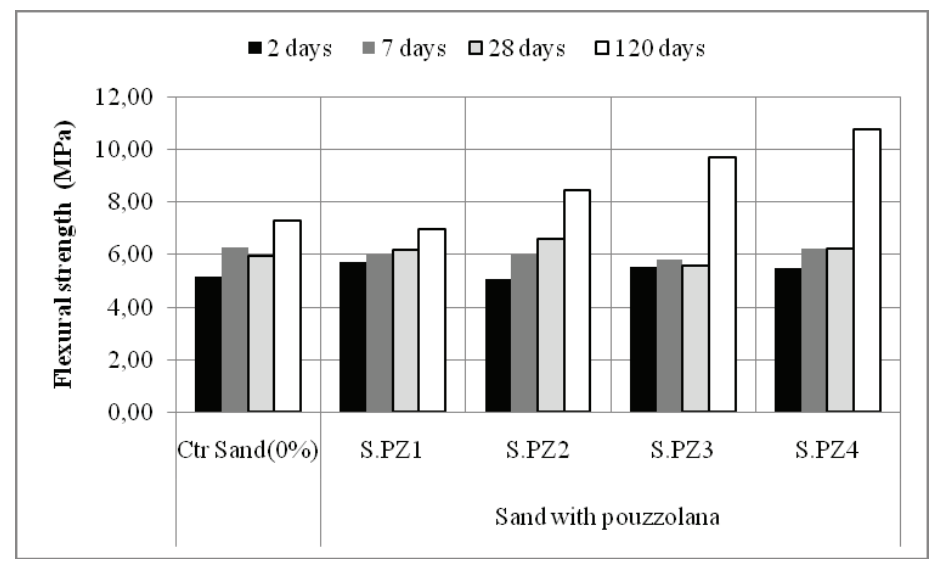

Fig. 3. Flexural strength development for different mixtures according to the age (sand with pozzolane) 
In this study we have found that the variation of the flexural strength has approximately the same values for either pozzolana or blast furnace slag based mixtures (Figs. 3 and 4). The difference can be noticed in the medium and long term or the recorded mechanical responses that sometimes exceeds $11 \mathrm{MPa}$, especially for sand-based mortars that contain more active additions specially mainly slag (Provis et al. 2014; Provis et al. 2015).

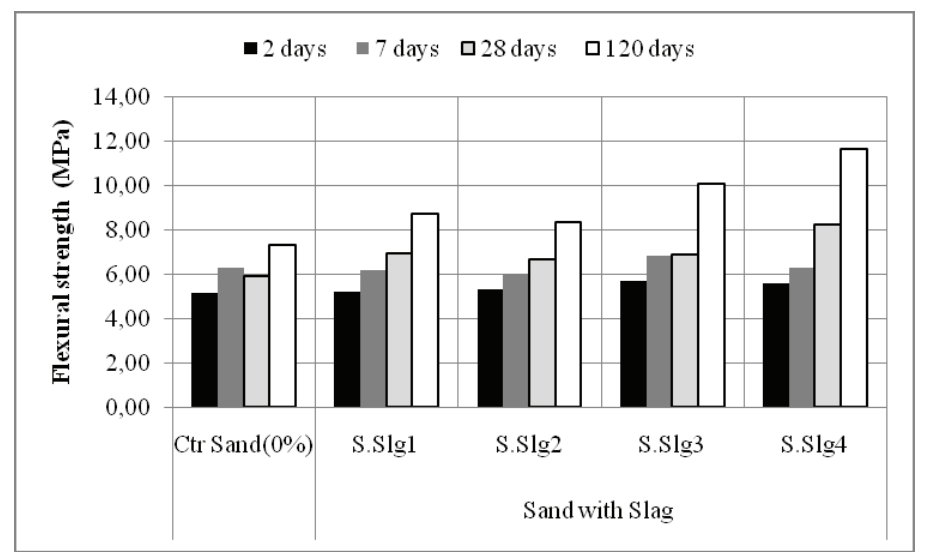

Fig. 4. Flexural strength developments according to the age for different mixtures (sand with Slag)

The rate of slag addition has a positive influence on the development of Flexural and compressive strength, and tends to decrease with lower dosages. The analysis of the results (Figs. 1-4) clearly shows that the compressive strength at 120 days is higher compared to those at 28 days. Although, all the mortars with additions developed resistances better compared to the control mortar.

The high reactivity of the slag leads to a reduction of the transition zone interface (paste - aggregate) whose adhesion becomes better, which influences the mechanical properties of the mortar (Gruber et al. 2001; Saillio 2012).

Further, It can be noticed from figures 3 and 4, that the flexural strength follows the same development trend like compression test along the age of testing. These values of flexural strength are more important compared to sand without additions based on natural sand.

The results of such combination for sand with additives contribute to the limiting of pores and make the cement matrix more compact hence, the improvement of mechanical strength.

This finding about the positive effect of additions for activated sand is due to the pozzolanic activity that improves the compactness of cementitious materials of the present research studied mortars. The results obtained are in accordance with previous research works on the subject (Fernandez et al. 2009; Noui et al. 2017). 


\subsection{DURABILITY}

The attacks of cementitious materials by sulphates or chloride penetration are very complex processes, several factors intervene such as the type of cement, the type of cation linked to sulphate, the concentration in sulphate, the mineral additions used and the period of exposure may affect mortar strength (Belagraa, Banfill 1989). In this context, the present experimental part studies the durability of prepared sand-based mortars which contain mineral additions in its particle size composition used as a partial substitution of fine fraction sieve size 0.08 to $0.16 \mathrm{~mm}$. The mortars obtained were put in exposure to two types of chemical solutions, sulfuric acid (at initial concentration of $37 \%$ ) and hydrochloric acid (initial concentration of $96 \%$ ) with a $\mathrm{pH}$ equal to 4.

Our objective is to obtain the impact of each addition and to choose the best rate for a better sustainability in an aggressive environment. The samples were exposed for 56 days in a hydrochloric acid $\mathrm{HCl}(5 \%)$ and sulfuric acid $\mathrm{H}_{2} \mathrm{SO}_{4}(3.5 \%)$ aggressive mediums.

The results obtained of loss of weight and resistances for the various mortars are presented in Figs. 5-8.

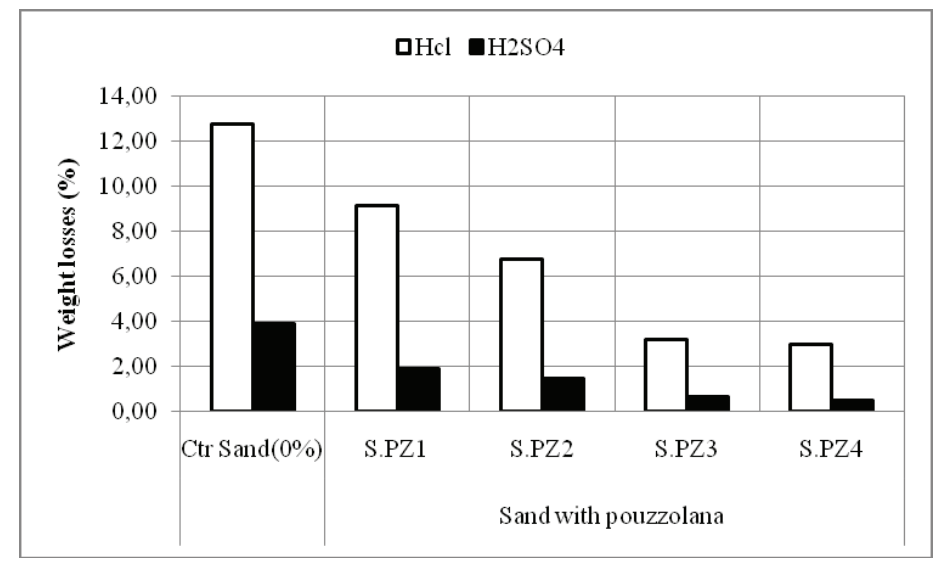

Fig. 5. Weight losses for different mixtures at 56 days (sand with pozzolan)

For all the immersed mortars in the $\mathrm{HCl}(5 \%)$ solution, after 56 days the hydrates of the control mortar had a more or less significant mass decrease, reaching $12 \%$ of weight loss and a drop in strength of $60 \%$, compared to sand-based combinations that contain a significant amount of the slag in its particle size composition (10\%), reaching a loss of weight lower in the order of $3 \%$ and a $28 \%$ drop in resistance. In the same trend the pozzolan-based sand mortars have given intermediate values of 34\% strength drop and $4 \%$ mass loss of weight in regards to the natural based quartz sand mortar (without addition). 
On the other hand, the immersion in $\mathrm{H}_{2} \mathrm{SO}_{4} 3,5 \%$ solution for the same curing period is in favor of mixtures higher pozzolan content, which achieves very slight losses especially for a substitution rate of $10 \%$ which does not exceed $0,51 \%$ and a resistance drop of the order of $3 \%$. Whereas, mortars based on slag sand composition are comes in the second position with a weight loss of $1,45 \%$ and a resistance drop of about $4 \%$.

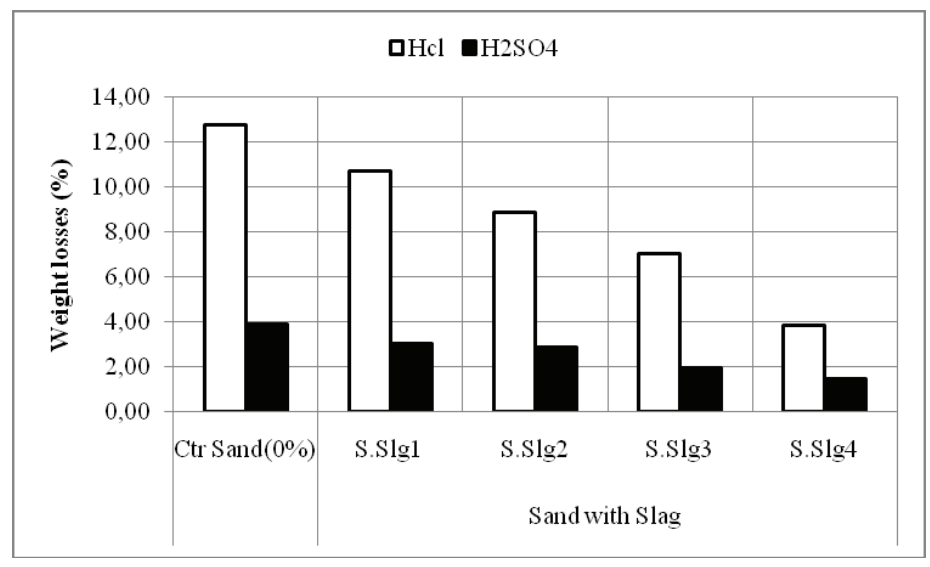

Fig. 6. Weight losses for different mixtures at 56 days (sand with slag)

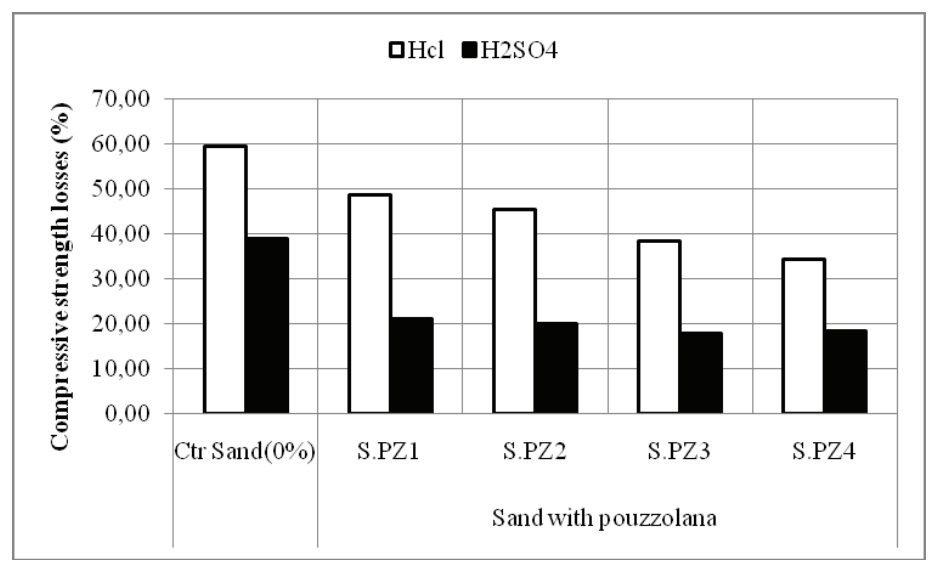

Fig. 7. Compressive strength losses for different mixtures at 56 days (sand with pozzolan)

It can be noted that the higher the rate of active additions, the greater degree of resistance to aggressive media, given that the weight loss of $6,7 \%$ and resistance drop $38 \%$ of the control mortar in both aggressive solutions compared to the mixtures based on activated sand with additions (slag and pozzolan) in its fine fraction. 


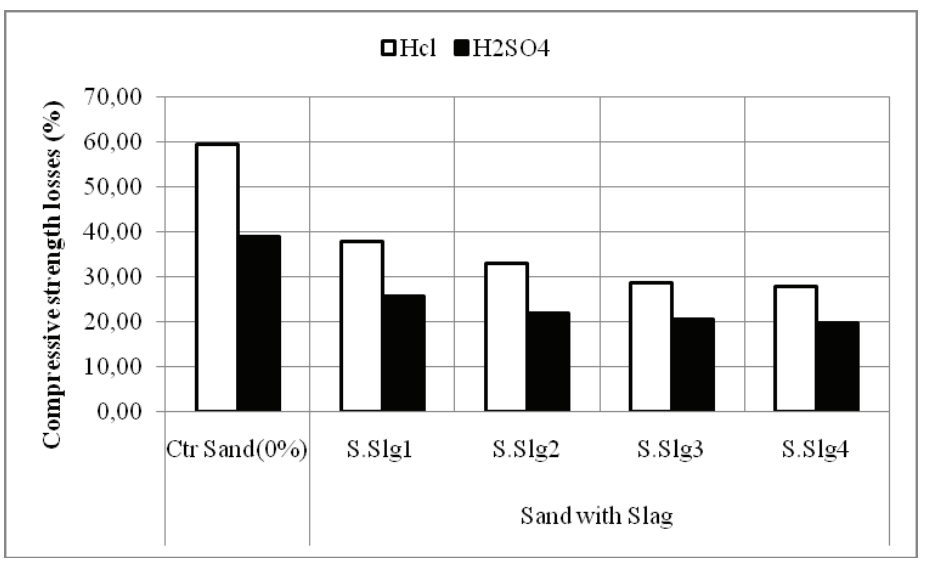

Fig. 8. Compressive strength loss for different mixtures at 56 days (sand with slag)

According to a recent study, the diffusion of sulphate or chloride ions is through the pores containing the interstitial solution in equilibrium with the phases of the cement matrix. The diffusion of chloride ions therefore depends on parameters such as the connectivity of the porous network, the resistivity and the fixing capacities of the cementitious matrices (Noui 2018).

Several studies have shown that the use of pozzolan or slag reduces the pore size and the connectivity of the porous network. As a result, the higher the rate of mineral additions, the lower the rate and the diffusion rate, provided the entire binder can react (which refers to kinetic problems). As the porous network is formed during hydration, the diffusion rates therefore depend on the degree of hydration of the binders, in other words on the degree of pozzolanic reactivity (Menendez et al. 2003; Deboucha et al. 2015; Saillio 2012).

\section{CONCLUSION}

This paper describes a preliminary study of the influence of prepared sand on the behavior of mortars and based on the obtained results, the following conclusions could be drawn.

The mechanical characterization of reactivity of the mineral additions used in sands composition confirms that there is an accelerated hydration reactions between Portland cement and prepared sands; this is explained by the pozzolanic effect of slag and pozzolana addition. The mechanical strengths are better compared to the control mortar $\left(R \mathrm{c}_{28}=43 \mathrm{MPa}\right)$ and reached a best case value of $55 \mathrm{MPa}$ at 28 days. The introduction of active additions in the prepared sands ensure the continuation of the secondary chemical reactions during the hardening period hence, an increase around $38 \%$ of the compressive strength of $70 \mathrm{MPa}$ after 120 days in water storage; this development is 
A. NOUI. et al.

due to the pozzolanic reactions between the cement and the additions. Thus, it leads to a better compactness and its porous network becomes largely reduced for the same cure period in comparison with the control mortar.

The originality of the research work here in is to highlight the differences between the resistivity of cementitious materials and exposure to aggressive media. Our study shows that these parameters strongly depend on the nature and the rate of mineral additions used, which can influence this diffusion or migration. Our recorded results confirmed the idea regarding durability improvement of resistivity against the aggressive solutions, especially for the activated sand mixtures at an optimal content of mineral additions ( $10 \%$ ), with a gain of mass loss by $75 \%$ and about $50 \%$ for strength.

Finally, it can be concluded that the use of mineral additions, slag and pozzolan could be beneficial for the composition of new types of environmentally friendly sand that could be used to formulate sustainable mortars in line with development objectives requirements.

\section{ACKNOWLEDGEMENTS}

The authors express their thanks and acknowledgements to all colleagues for their contribution in the preparation of the present paper. The staff of the laboratory of civil engineering, faculty of science and technology is congratulated for their technical support in achieving the experimental program.

\section{REFERENCES}

ALONSO S., PALOMO A., 2001, Alkaline activation of metakaolin and calcium hydroxide mixtures: influence of temperature, activator concentration and solids ratio, Materials Letters (Roč. 47). http://doi.org/10.1016/S0167-577X(00)00212-3

BADOGIANNIS E., 2002, The effect of metakaolin on concrete properties. Proceedings of International Congress: Challenges of Concrete Construction, Dundee, 81-89.

BELAGRAA L., BOUZID A., 2016, performance study of low environmental impact mortars based on mineral additions and cement resistant to sulfate (crs), Mining Science, 23, 65-76.

BURCIAGA-DIAZ O., DÍAZ-GUILLÉN M.R., FUENTES A.F., ESCALANTE-GARCIA J.I., 2013, Mortars of alkali-activated blast furnace slag with high aggregate: binder ratios, Construction and Building Materials, 44, 607-614, http://doi.org/10.1016/j.conbuildmat.2013.03.057

CASSAGNABÈR E.F., LACHEMI M., MOURET M., ESCADEILLAS G., 2011, Caractérisation performantielle d'un liant ternaire à base de ciment, laitier et métakaolin, Can. J. Civ. Eng., 38, 8, 837848.

CHEN C., GONG W., LUTZE W., PEGG I.L., ZHAI J., 2010, Kinetics of fly ash leaching in strongly alkaline solutions, Journal of Materials Science, 46, 590-597. http://doi.org/10.1007/s10853-0104997-z

CRIADO M., FERNÁNDEZ-JIMÉNEZ A., PALOMO A., 2010, Alkali activation of fly ash. Part III: Effect of curing conditions on reaction and its graphical description, Fuel, 89, 3185-3192. http:// doi.org/10.1016/j.fuel.2010.03.051

DEBOUCHA W., OUDJT M.N., BOUZID A., BELAGRAA L., 2015, Effect of Incorporating Blast Furnace Slag and Natural Pozzolan on the Compressive Strength and Capillary Water Absorption of Concrete, 7th Scientific-Technical Conference on Material Problems in Civil Engineering MATBUD '2015, Cracow, 22-24 June 2015, Cracow, Poland. 
EN 12390-3 (2009), Compressive strength at 28 days.

EN 12390-6 (2003), Splitting tensile strength at 28 days.

EN 196-1 (2003), Determination of strength, Method of testing cement.

FERNANDEZ-JIMENEZ A., PALOMO J.G., PUERTAS F., 1999, Alkali-activated slag mortars Mechanical strength behaviour. Cement and Concrete Research, 29, 1313-1321. http://doi.org/10.1016/ S00088846(99)00154-4

KERBOUCHE A., MOULI M., LAOUFI L., SENHADJI Y., BENOSMANE S., 2009, Influence des ajouts minéraux sur les résistances mécaniques des mortiers. SBEIDCO - 1st International Conference on sustainable Built Environment Infrastructures, in: Developing Countries ENSET Oran (Algeria), 431-438.

KHATIB J.M., 2004, Absorption characteristics of metakaolin concrete. Cement and Concrete Research, $34,19-29$.

LIZCANO M., KIM H.S., BASU S., RADOVIC M., 2011, Mechanical properties of sodium and potassium activated metakaolin-based geopolymers. Journal of Materials Science, 47, 2607-2616. http:// doi.org/10.1007/s10853-011-6085-4

NOUI A., 2018, Effet de l'activation du ciment avec ajout minéral par la chaux fine sur le comportement mécanique du mortier, thèse de Doctorat, département de Génie Civil, Université de M'sila, Algérie.

NOUI A., ZEGHICHI L., 2017, The effect of limestone fineness on ternary cement fresh-state and early-age properties, Mining Science, 24, 195-208.

POUGUININSELI M.L., 2017, Étude de l'influence de la qualité du sable sur les propriétés physicomécaniques d'un béton courant: Mémoire pour l'obtention du master en ingénierie de l'eau et de l'environnement option: genie civil 2017, ACIT Géotechnique Burkina Faso.

PROVIS J.L., VAN DEVENTER J.S.J., 2009, Geopolymers - Structure, processing, properties and industrial applications, Woodhed Publishing Limited and CRC Press LLC.

PROVIS J.L., VAN DEVENTER J.S.J., 2014, Alkali Activated Materials State-of-the-Art Report, RILEM TC 224-AAM. RILEM State-of-the-Art Reports. New York, London Library.

PROVIS J.L., PALOMO A., SHI C., 2015, Cement and Concrete Research Advances in understanding alkali-activated materials, Cement and Concrete Research, 78, 110-125.

SAILLIO M., 2012, Interactions physiques et chimiques ions-matrice dans les bétons sains et carbonatés. Influence sur le transport ionique, Université Paris Est Marne la Vallée.

SEDIRA N., CASTRO-GOMES J., KASTIUKAS G., ZHOU X., VARGAS A., 2017, A review on mineral waste for chemical-activated binders: mineralogical and chemical characteristics, Mining Science, 24, 29-58.

TÜRKER H.T., BALÇIKANLI M., DURMUS I.H., ÖZBAYA E., MUSTAFA E., 2016, Microstructural alteration of alkali activated slag mortars depend on exposed high temperature level, Construction and Building Materials, 104, 169-180, http://doi.org/10.1016/j.conbuildmat.2015.12.070 